\title{
Disintegration of the family in Cairo House 2000 by Samia Serageldin "A sociological literary study"
}

\author{
A research Paper By \\ Hany Mohamed Bahaa EI Deen \\ A lecturer in Sociology \\ Faculty of Arts \\ Suez University
}

\begin{abstract}
The study of literature and art is not a sociological one, as some might think. Both are a phenomenon of human social phenomena whose existence and development are linked to the development of culture. This is a human innovation that reveals in its content and form the extent to which human groups understand and understand the universe, the world, and the surrounding environment. The novel of Cairo House by Samia Serageldin, published in English, is a novel that is woven from different braids, from autobiography to the diaspora literature to the existential philosophical narrative, to historical literature and sociological literature. All these factors make it an ideal example of postcolonial literature. It all overlaps to create a harmonious, beautiful braid whose locks do not Alienate, but embrace warm intimacy despite the cruelty of life towards the heroine of the novel Gigi. Samia Sirajuddin, an Egyptian-American, writes an imaginary autobiography unfolding, in vibrant details and fertile fiction, the eras that once were before July Revolution in Egypt 1952. She transfers her readers across a stunning journey through cultures within cultures. The Cairo House is more than just a novel about Cairo though. It is a preface to the changing periods and the stylishness that once was in a pre-Nasserite Egypt.
\end{abstract}

Keywords: The Cairo House, The 1952 Revolution, Social changes, Disintegration of the family. 


\section{مجلة وادي النيل للاراسات والبحوث الإنسانية والاجتماعية والتربوية (مجلة علمية محكمة)}

(ISSN : 2536 - 9555)

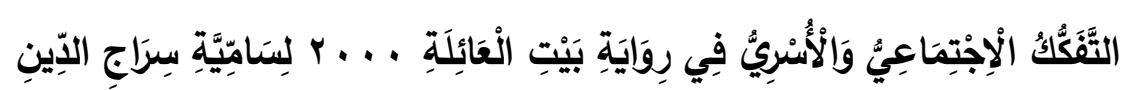

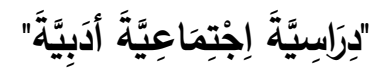

$$
\begin{aligned}
& \text { د. هَانِي مُحَمَّدِ بَهَاِِِ الآِّين } \\
& \text { قسم علم الاجتماع - كلية الآداب - جامعة السويس - مصر } \\
& \text { د. وَلِيدِ عَبْدِ اللَّهِ ِِذِقِ } \\
& \text { قسم اللغة الانجليزية - كلية الآداب - جامعة السويس - مصر ليل }
\end{aligned}
$$

الْمُسْنَخْلَصِ:

دراسة الأدب والفن ليست دراسة اجتماعية، كما قد يعتقد البعض. بل كلا هاتين

الظاهرتين ظاهرة اجتماعية بشرية يرتبط وجودها وتتميتها بتمية الثقافة. وهذا ابتكار بشري يكثف في محتواه ويشكل مدى فهم الجماعات البشرية للكون والعالم والبيئة المحيطة. رواية بيت العائلة لسامية سراج الدين، الذي نشر باللغة الإنجليزية، هو رواية

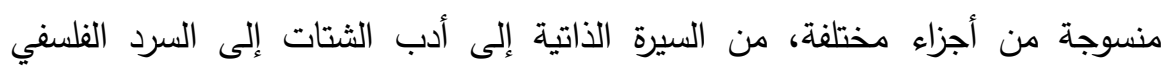
الوجودي، إلى الأدب التاريخي والأدب الاجتماعي. كل ذلك يتداخل لخلق شجاعة إناء

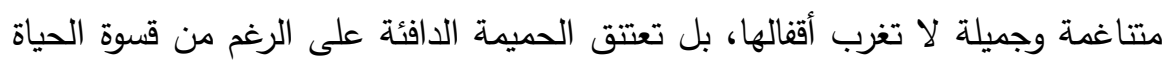
تجاه بطلة الرواية جيجي والتي عانت من التفكك الاجتماعي والأسري بعد ثورة يناير

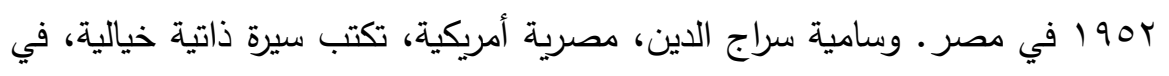
تفاصيل حيوية وخيال خصب، بتركيز على الحياة في مصر قبل ثورة يوليو وبعدها.

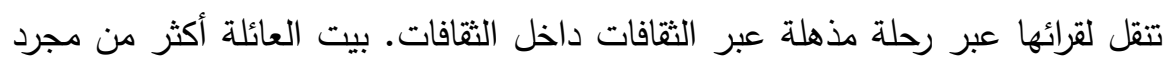
رواية عن القاهرة. إنها مقدمة للفترات المتغيرة وأسلوب للحياة الذي كان ذات يوم في مصر ما قبل الناصرية. الكلمات المفتاحية: بيت العائلة، ثورة وO0 190، التغيرات الاجتماعية، تفكك المجتمع والأسرة. 
Disintegration of the family in Cairo House 2000 by Samia Serageldin

"A sociological literary study"

Hany Mohamed Bahaa El Deen \& Walid Abdallah Rezk

مجلة وادي النيل للاراسات والبحوث الإنسانية والاجتماعية والتربوية (مجلة علمية محكمة)

Disintegration of the family in Cairo House 2000 by Samia Serageldin

"A sociological literary study"

\section{Introduction}

The novelist Samia Sirajuddin was born in Cairo and emigrated with her family to the United States in 1980. She was awarded a master's degree in political science from the University of London. She is one of the granddaughters of the great family of Serageldin whose origins extend to El Garida village in Kafr El Shiekh in Egypt. She is the daughter of the famous lawyer, Sami Serageldin and the granddaughter of Fouad Serageldin, the head of Al-Wafd party. She graduated from the University of London. Currently she lives with her Egyptian husband and live in Los Angeles in the United States, they have two sons Ramy and Kareem who work in banking. One lives in London and the other is in the city of Los Angeles.

\section{Method of Research}

The history of Egypt, the biggest Arab country, is complicatedly related to the cultural, social, and economic history of the whole area, and in many cases, the whole world itself. Novels written about Egypt frequently mirrored the Colonial periods, written from "foreign" viewpoints. According to Nasrullah Mambrol "postcolonial literature explores issues of cultural alienation, and it struggles to express the specificity and particularities of indigenous cultures in languages that are not generally the original languages of the indigenous peoples but rather the languages of the former colonizers." (2019) Samia Serageldin, an Egyptian-American writer, interlaces a wonderfully crafted image of pre-revolution and Nasserite times up to 1970s through the eyes of Gigi, her alter ego, and the heroine of her masterpiece Cairo House. The writer was born into an aristocratic family whose domain was tattered by the revolution of Egypt in 1952. As a member of the Egyptian nobility so cruelly hunted 
(ISSN : 2536 - 9555)

down by the president of Egypt Gamal Abdel Nasser, she loans her memories to Gihan Seifeldin to carry readers across time, and sometimes space, in a story based on her childhood family palace. The author uses postmodernism method to express her ideas and thoughts with an expert use of its main tools like metafiction, selfreflexivity, unreliable narration, and intertextuality. The study proposes several questions including, how does the Cairo House represent a witness to the history of Egypt between 1952 to 1990 ? Is Cairo House a good example of post-colonial literature? Does the Cairo House succeed in giving a true picture of Nasser's rule of Egypt? Does the 1952 succeeds in achieving social justice? Does the revolution damage family ties of a group of people whose only sin that they are landowners? Does the heroine find her roots when she comes back to Egypt? The study focuses on the different viewpoints of people coming from different classes in Egypt. Some people really got many benefits from the revolution, but it damaged the lives of many people as well including the writer herself and her heroine.

Writing an autobiographical justification of their Arab female writers without affronting conventional conservative family members is no easy task! In the Cairo House, for example, Samia Serageldin's semi-fictional narration of her life leaves out any provocative details. Nothing too private, nothing too sensitive. While this could have instigated the novel to be a little tedious and instigated, Ms. Serageldin manages to pull it off because of the chronological fertility, and brilliant imagery of her own life.

To be sure, 1952 is a fateful year in modern Egyptian history. On July 23 of this year, the Egyptian Army Revolution, known as the "July Revolution," took over the July Revolution and proclaimed its basic principles. To achieve these principles, the revolutionary government's first law was the Agrarian Reform Act, and then "abolished the parties that the revolutionary government saw as an impediment to democracy, the rich's wealth, and the property." (Yousif 13). 
Disintegration of the family in Cairo House 2000 by Samia Serageldin

"A sociological literary study"

Hany Mohamed Bahaa El Deen \& Walid Abdallah Rezk

مجلة وادي النيل للاراسات والبحوث الإنسانية والاجتماعية والتربوية (مجلة علمية محكمة)

Historian Abdul Rahman al-Rafei wrote about the July revolution: "The July revolution also affected the form of political life, and its impact was reflected directly on the literary, critical and intellectual movement. There is a strong relationship between art and politics. The first cannot achieve its social function unless it is political. Artists, critics, and writers must have a political doctrine that keeps pace with the developments of social movements. "Therefore, everyone admitted that the July Revolution was a hit by the pulse of the masses, and therefore the revolution of creativity and creativity started with it." (Al-Rafeea 168).

An astonishing and puzzling novel tackles the struggle of an established Egyptian family to confront the post-World War II upheaval in Cairo. Gigi grew up in one of the luxury palaces of Garden City. She has her big family, where men are engaged in politics, business, and cotton farming. Women are involved in the exchange of visits, gossip, shopping, arranged marriages and other family matters.

The house was always open to visitors, politicians, and the family, and there the original Egyptian generosity was mixed with cosmopolitan behavior. It was a fascinating world, and it looked immortal, as the Pashas' era was about to fall. When many were forced to leave Egypt, those who remained faced a bitter reality.

Gigi is a modern woman of conservative origins facing the conflict between accepting traditional marriage and losing the family, exile, and the need to establish a new life on the one hand, and to preserve its roots on the other.

Egypt's social and economic conditions worsened between 1936 and 1952 in unprecedented ways. At that time, Egyptian society witnessed a sharp decline, a clear deterioration in its construction and a big disparity between its classes. However, the main phenomenon that characterized Egyptian society at that time was the rise of the rich, despite their small numbers, and the 
(ISSN : 2536 - 9555)

increase in poverty, which "made the gap between rich and poor, in addition to the lack of social justice Inside Egyptian society." (Ashour 138).

The Egyptian economy was dominated by a group of Egyptians and foreigners who were interested only in making profits and accumulating money at the expense of the people who suffered from hunger and disease. It was very natural that the gap between those who controlled all the fields and sectors of the Egyptian economy and the Egyptian people who were living under exploitation and injustice would widen the gap. Worse, "that segment of the Egyptian diaspora that was controlling power in Egypt seemed happy. That authority was pleased with life and did not care about the poverty of the people." (Khalaf 75).

There is another danger that increased social disparities in this period in Egypt's history. The rich increased demand for land, which made agricultural property the only means of saving, and the rich ran into buying agricultural land. This led to higher prices, which resulted in higher value for agricultural crops and higher prices in the country, in addition to higher prices The rich towards using their money to buy land, which not only increased social disparities through the inflation of small property, but also embodied in the "departure of capital from industry and manufacturing, which made the country live dependent on foreign imported goods and commodities." (Ashour 139).

It was the duty of the Egyptian government to intervene to uphold social justice among the classes, without depriving them of the fruits of their activities and efforts. "The proper social orientation required the government to reduce the great differences among the classes of the people as much as possible." (Al Rafeea 168).

The story begins with the scene of "Gigi" coming back from the United States to Cairo on a special mission. She is looking for two children, as a child she left behind when she fled her husband to Paris ten years ago. A girl, who was the same writer when she was a child, rushed to a decision she later regretted when she 
Disintegration of the family in Cairo House 2000 by Samia Serageldin

"A sociological literary study"

Hany Mohamed Bahaa El Deen \& Walid Abdallah Rezk

مجلة وادي النيل للاراسات والبحوث الإنسانية والاجتماعية والتربوية (مجلة علمية محكمة)

married an aristocrat whom she knew nothing but that his father was a senior lawyer, businessman, and a family friend.

I have come back to claim what's mine...to find two children I left behind when I ran away a decade ago: one child is my son and the other the girl I once was. The future and the past. Between them they hold the key to the question I have come to resolve: where do I belong? Where is this chameleon's natural habitat? (2).

His mother was a friend of her aunt, whom she nominated to him to get to know quickly, marry her and fly with her to London, where he studies and works until he returns to Egypt, to become with the influence of his powerful controlling father and his relationships among the richest men in Egypt in the era of openness.

Serageldin gave us a parallel story, which was based on the fact that the names of her hero Jihan and her son Tamer were similar to those of our hero Gigi and her son Tarek, although these names are more similar in English than in Arabic.

The writer says about Jihan that she was never happy with her husband after he neglected her for his career as a "cardiologist" who became later Gamal Abdel Nasser's personal doctor. She left him, married a Lebanese, and emigrated with him to Lebanon, leaving behind her son "Tamer".

The writer says on Jihan's side that she should have considered the teenage girl who was standing in the corner of the room when she came to say goodbye to her father, who was the reason she knew about her first husband Ali. She wondered: "Does one realize that when they are diving in water, the successive circuits that they are making over the surface of the water will inevitably reach the other shore? She said it, predicting a second story with Gigi, our heroine, who will follow the footsteps of her cousin Jihan in a few years. 
(ISSN : 2536 - 9555)

Serageldin also took us on a geographic journey from Cairo, the aristocratic, the days of the Pashas, the legendary palaces, the high-class education, the literature, the high-level living details of aristocratic Egypt and even its middle class. The writer tours us through an exhausting trip to London, Paris, and then New Hampshire, in the United States, where she feels isolated, alienated and longing to return to Egypt. Although it seems difficult to compare between these cities and Cairo, the latter always won the bet, and urges Gigi to return and settle there despite the circumstances that pushed her to emigrate again every time.

The title of the novel, The House of Cairo, which was recently translated into "The House of the Family", is the link between the past of "Gigi", the aristocratic child full of life, who reads about the world and its morals without interruption, and seeks to reveal all secrets, even the slaughter of the Eid sheep before dawn in a back garden booth, which she wants to see and know its secrets and her present now as an exhausted mature lady.

She looks for herself among all the cities of the world and she thinks she finally found herself in the old palace in Cairo, but this is impossible! The "House of Cairo" becomes a symbol of the aristocracy that it used to be for Prince Bandar, who was a friend and partner of the father of Youssef, paid lucrative sum of money to buy it. After that her first husband took her to live in London for a while, then left for Jeddah to live at Prince Bandar's palace ten years ago, where she met with Princess Khadija, the prince's wife, whom the writer cleverly describes as living in a luxurious prison with everything Apart from freedom, he personally led her to the path of a blocked divorce, and fled to Paris and left her son "Tamer" to take care of her mother, because of Youssef's insistence that he live with him in the Prince's Palace in Jeddah for a few years until the completion of a project that brought him together with the prince.

The revolution is a social struggle waged by the masses to bring about fundamental changes to the socio-cultural economic 
Disintegration of the family in Cairo House 2000 by Samia Serageldin

"A sociological literary study"

Hany Mohamed Bahaa El Deen \& Walid Abdallah Rezk

مجلة وادي النيل للاراسات والبحوث الإنسانية والاجتماعية والتربوية (مجلة علمية محكمة)

structure (the existing regime), to deny existing economic and social relations, and to establish a new system of relations and to benefit the masses. "It's aimed at eliminating the infrastructure and the infrastructure that you serve and creating a new system with a new infrastructure and an identical superstructure." (Fonon 2012).

Family disintegration is considered one of the most important problems facing all societies due to the waves of rapid social and cultural change. This change led to a construction and job imbalance, "which led to tension, conflict, and the emergence of the possibility of disintegration within many families." (Gaith 153), Gigi always has the sense of loss and unbelonging to a place while she was on the plane coming to Egypt, she was asked by a couple her country and her answer was "I live in New Hampshire" (2) and there is a big difference between I live and I am from, she didn't really know what she should say. She continued saying "It is only any answer I give will just in complete and misleading, so this is as good-or bad-as any other" (2).

The first setting of the novel is the airport and has several implications, it is the most convenient setting for people like her "whose past and present belong to different worlds, it is a traditional limbo" (1), carrying her American passport and when the officer sees her name Seif-el Islam says "Hamdillah alsalama, welcome home"(5), getting out of the gate and seeing the couple who asked about her country and her eyes say "I no longer belong to your world"(5).

To offer some answers to her heroine, Serageldin divides her novel into three parts, starting her novel with "Photographs" which starts directly after reaching her home. She resorts to the photographs of her mother's album to overcome her insomnia which is a result of jet lag but mostly the noise. She looks at black and white pictures which represent past day that she longs for and others in color to represent her current life and compares between her life as a child and as an adult now. 
(ISSN : 2536 - 9555)

Gigi looks at the album and stops on two pictures which form a turning point in her life, the first one was taken with her parents just before Eid Al-Adha in 1961. She remembers Nasser's speech on the $9^{\text {th }}$ anniversary of 1952 revolution and his repeated references to her family and others as "the enemies of the people" (20). She also remembers how her family members were direct victims of such a revolution and left most of them penniless, imprisoned or marginalized from political life even her father was classified as "invalid" (74). Despite her family's several attempts to hid this terrible truth from her, she felt and suffered that horrible reality which she couldn't escape from even at school, the situation was much worse as she was surrounded by groups of her school mates whispering about her and calling her "la pauvre petite." or the poor girl in English.

Gigi also recalls the occasion of her birthday which was completely different after the revolution and Nasser's takeover her family's wealth. She remembers her party which was free of most of her school mates and attended by a distant cousin as a result she was told that it was better not indulge in relationships with other people because of sequestration. At that moment she felt outcast and Mona Russel comments on this situation saying that "despite Gigi's young age she became persona grata" (Russel 5). She keeps recalling sad incidents in her life and concentrates on a situation that happened at school while the Arabic teacher explaining the new mandatory subject the Arabic Socialism and repeating the term "the enemies of the people" while looking at her and her cousin referring to landowners and capitalists. She also remembers how her life was really difficult when "the intelligent agent at the door took note of every visitor, the telephone was tapped and the servants were spies" (42). Consequently, very few people risk visiting them, she felt she was living in an open jail, she suffers from her awareness of:

Bearing the burden of belonging. You could not help it, when the mention of your last name invariably provoked a reaction not always easy for a child to read: dread or pity, envy, or commiseration. You grow up 
Disintegration of the family in Cairo House 2000 by Samia Serageldin

"A sociological literary study"

Hany Mohamed Bahaa El Deen \& Walid Abdallah Rezk

مجلة وادي النيل للاراسات والبحوث الإنسانية والاجتماعية والتربوية (مجلة علمية محكمة)

unable to reconcile family loyalty with the virtual rhetoric from public podiums" (27).

Accordingly, the first part of the Cairo House carries details about Gigi's complicated and uneasy childhood. She not only suffered at her home, but she suffered at school as well. These incidents left her an abnormal person who has a difficult life as she cannot get on well with all the people surrounding her in addition to the political and economic instability in Egypt which made her think to leave her country. Her repetitions of "the good old days" and "before the revolution" gives us a sense that she was a normal child who lived in an ideal world of her own before the revolution who changed completely after the revolution. What makes that feeling stronger may be her foreign education which made her somewhat away from the culture of her own country as she went to a French school and spoke at home in French with her family and her nanny, Helen, who represents another good example of a displaced person whose past is really tough as she was married to an Italian businessman who had a lot of properties but were dispossessed by the British during the Second World War. After the death of her husband, she had to work as a governess to earn her living until she dies, and no one notices her death which is sometimes the case with the displaced.

Gigi has a very different feeling towards her Egyptian maid, Om Khalil, whom she feels very strange to her. She remembers how they used to treat her very kindly and how generous her family was with her while she was working for them. She was angry with Om Khalil when she sighed bitterly after the death of Nasser saying, "our father is gone" (67). Gigi was really shocked because Om Khalil knows well that Nasser is Gigi's family's "avowed enemy" (67). This situation proves that Gigi was not aware of the lower class in the Egyptian society especially the peasants, she even states on their reaction to the 1952 revolution that "the fellahin accepted the momentous change with their usual mixture of resignation and indifference" (40). Gigi even did not 
(ISSN : 2536 - 9555)

understand their language and very weak in Arabic and could not understand some Egyptian common idioms such as the one used by their cook talking to her mother "he owed them the flesh of his shoulders" (21). which means he owes them his livelihood.

When her father advised her once to read Naguib Mahfouz's novels, she could not assimilate his characters or settings and found the "depressing" (45). Her world is completely different from Mahfouz's world which represents the Egyptian society. She remembers whenever she moves around the different neighborhoods of Cairo on passing by:

Some of these back alleys, she would bury her nose in a French novel avoiding the sight of the beggars, the carcasses of meat hanging on hooks in front of the butcher shops, of the flies on children's faces, of the peasant woman sitting cross-legged on the railway station platform, suckling a baby on one swollen bare breast" (45).

It was obvious throughout the novel that there is a very wide gap between Gigi's own world and the society in which she lives. She remembers her husband's aunt remarks about the style of her life and describing her as "Europeanized" (37). However, she usually tries to show how her family members are deeply rooted in the Egyptian soil. She states that the culture she was brought up in was a "hybrid culture" where "western norms and customs were in some instances unhesitatingly sacrificed on the altar of tradition" (11). She mentions that the western culture dominated but "the spirit of hospitality was uncompromisingly Egyptian as that of the country people which she so many talks about.

The second photograph stops her was of her father, Shamel, his friend Ali Tobia and her father's lovely niece, Gihan or Gina. Later we know her father played an important role in the marriage of his friend Ali and his niece Gihan although Ali was refused before because Gihan's father thought Ali was after the fortune of the family and due to the modern lifestyle adopted by his sisters who "drive cars and smoke in public" (37) Gina too was 
Disintegration of the family in Cairo House 2000 by Samia Serageldin

"A sociological literary study"

Hany Mohamed Bahaa El Deen \& Walid Abdallah Rezk

مجلة وادي النيل للاراسات والبحوث الإنسانية والاجتماعية والتربوية (مجلة علمية محكمة)

classified as a different woman from those of her day. She was a rebel as she insisted on getting married to the man, she loved despite her family rejection. After the revolution, her husband was the only one that became wealthier and more successful, but it was at the expenses of his family life, for his wife soon fell in love with another Lebanese man, divorced and decided to leave Egypt and went to see her favorite uncle, Shamel, off. He was harsh with her and simply told her "goodbye" (41). He never recovered that shock and could not forgive Gina for disillusioning him and breaking his heart and his friend's as well. Gigi was watching that farewell scene and left a deep mark on her heart to an extent that she states, "Do we ever realize what a far-flung web we weave by our actions?" (176). She decides never disillusions her father in such a way and goes on saying "But there was no way anyone could have imagined then that Gina's story would lie like a palimpsest undermine, long after it had faded from memory" (42).

Gigi moves to another group of colored pictures which implies a change in time and feelings and looks at herself aged nineteen and completely different from the nine-year-old girl in the black and white pictures. At the age of nineteen she resorts to what Mona Russel calls "retreats to a world of books and imagination" (2) escaping that political and economic unrest in her own country as she was suffering from a very deep feeling of insecurity. Whenever she speaks of Nasser's police state or El-Raiis, as she used to call him, with thousands of ears and eyes lurking at every corner" (44) She no longer has a normal sleep, she goes on describing the consequences of Nasser's terrible regime:

Nasser's sequestration decree went far beyond the confiscation of wealth or the stripping of civil liberties. It was sharply honed instrument of his malice: it isolated, it muzzled, it humiliated, it stigmatized, it forced retirement on men in their prime, it immured them in their homes" (44). Even the women in the family were under constant 
مجلة وادي النيل للاراسات والبحوث الإنسانية والاجتماعية والتربوية (مجلة علمية محكمة)

(ISSN : 2536 - 9555)

surveillance and went on whispering, long after Nasser's death, out of habit" (46).

In an interview with Samia Serageldin, she states that "as a child, she (Gigi) had been quite feisy and curious, but the traumatic experience of witnessing the Eid Al- Adha sacrifice (exaggerated in her childish mind) plus the circumstances of the sequestration, dampened her spirit and made her a docile young girl" (Sharobeem, interview).

With her marriage, a new stage of isolation, loneliness and strangeness begin in the second part of her novel which is entitled "Exile". This feeling is due to two main reasons. First, she was away from home and her family, living in a cold strange country, England for the first time in her life. Second, she was psychologically lonely as she did not love her husband from the very beginning, but she did not want to shock her father again with younger Gihan. She moved to Saudi Arabia with her husband which gave her no real feelings of stability. Gigi also remembers herself as a mother for the first time when she gave birth to her first child Trek, which was a turning point in her life and personality:

If you examined the turning points in a life, could you pinpoint the exact twists of the kaleidoscope that set the pattern? If you could go back in time and change course, would you? Or would there be some part of the past that you would be unwilling to give up for a second chance? A child, it has been said, is your hostage to fortune: henceforth your choices are never free" (72).

Accordingly, she decides to give another chance to her husband Yussef for the sake of her son and bear the feeling of strangeness in London for five years until she goes back to Egypt, dreaming of having a stable family life which is shattered when she left for Saudi Arabia for work. She has a new cultural shock due to the life style and Saudi Arabia which is totally different from hers, for she can't travel to Jeddah without a Mihram "guarantor and has to wear hijab whenever she moves around or goes out of the house" (80). 
Disintegration of the family in Cairo House 2000 by Samia Serageldin

"A sociological literary study"

Hany Mohamed Bahaa El Deen \& Walid Abdallah Rezk

مجلة وادي النيل للاراسات والبحوث الإنسانية والاجتماعية والتربوية (مجلة علمية محكمة)

Gigi cannot cope with that kind of life in Saudi Arabia and decides to go back to Egypt and lives in her father's house. The death of her father finalized her marriage. "when her father dies, she is freed from the constraints of trying not to disappoint him, and she acts decisively in seeking a divorce, which traps her into running away" (Sharobeem, interview). It is the first time to take an important decision concerning her life, may be hard times make her much stronger:

Sometimes it takes almost an imperceptible shift in the kaleidoscope for the pattern to come into focus. Sometimes all it takes is the removal of one silver of colored shapes for the entire image to change. It seemed that in her life, endings and beginnings were marked not with a bang, but with a whimper. But this time, at least, she had not merely floated along like a leaf downstream. This time she had taken a decision. (97).

The decision of divorce opens the exile phase in her life, first in Paris and then in New Hampshire. As an act of revenge, Yussef revokes the divorce and therefore, it is impossible for her to return to Egypt, or she will be under his mercy and control. She states about her decision saying" When she had left, she had fled as if she were escaping a trap about to close on her. Now she felt as if she were in exile, waiting for her sentence to be commuted in order to return" (125).

With her second marriage, another stage of exile starts in the United States. And in stead of living temporarily in New Hampshire, she stays for ten years where she has no family members with the absence of any sense of rootedness, she begins to form a new person when she remarks "some part of her mind had difficulty recognizing the Gigi of old in the woman she had become in this northern town of snowcapped steeples and ice hockey" $(138,139)$. 
مجلة وادي النيل للاراسات والبحوث الإنسانية والاجتماعية والتربوية (مجلة علمية محكمة)

(ISSN : 2536 - 9555)

Therefore, after ten years of being away from her roots, she needs to go back to her homeland to restore her original culture and identity. The main reason behind her desire to return was because "Even to herself she had become something of a stranger, her native language no longer came naturally to her tongue, the memories of her old life seemed to have taken place in another dimension" (139).

If we go back to the circumstances surrounding Egypt since the Second World War in particular, we will find that they represented an increase in the severity of the contradictions in Egyptian society. "This is reflected in the social, economic, political, and military situation, which was one of the main reasons for the revolution." (Rateb 63).

The characters are all alive and blooming all through the novel. One feels a feeling and a sense of belonging with them by the middle of the narration, and one does not want to leave them at the end. Rare are the novels that arouse such feelings for the entire cast of characters, not just the main character. However, at turns of the story, the character progress leaves the reader wondering, one occasionally feels like they can see and tell fact from fiction.

Politics and history side by side, the book is a story not just about what once existed, but also about how subtle the sense of belonging is. If one has ever wondered how being "uprooted" feels like, they should read Samia Serageldin's description of her life journey. It is immensely amusing and thought infuriating.

Serageldin describes the political curve that appears throughout her long journey. She does not hide her hatred for Gamal Abdel Nasser, his revolution, and men, who carelessly turned Egypt upside down, and his private doctor Ali, Gihan's husband, whom Abdel Nasser killed for diagnosing him with 
Disintegration of the family in Cairo House 2000 by Samia Serageldin

"A sociological literary study"

Hany Mohamed Bahaa El Deen \& Walid Abdallah Rezk

مجلة وادي النيل للاراسات والبحوث الإنسانية والاجتماعية والتربوية (مجلة علمية محكمة)

paranoia, Indirectly, he caused her father's depression, and then his death.

With her decision to go back to Egypt to see her child Tarek, to feel like an insider and get reacquainted with the country, the third and last part of the novel, the "Return" begins. One feels that like Lisa Majaj, our heroine "longed not to be defined by the gaze of the other, but to look out upon the world through eyes rooted in the boundaries of her own identity" (Majaj 67). In Egypt Gigi starts getting the same old feelings as if she had never gone away and feels more alive than she has been in years. She starts to see her marriage to Luc as if it belonged to the past and reconsiders separating from him to start her life back again in Egypt. All the years she spent in New Hampshire "seemed so far away, another world, and the past ten years seem like an interlude, a sharp zig in the flat line of experience, a detour in the insurmountable bump in the road" (201). Like true chameleons, she realizes that once she has blended into a new environment, it becomes difficult to imagine herself anywhere else. Therefore, with the approach of the end of her stay in Egypt, she begins to wonder "How can I give up what I have been looking for, waiting for, for so long? How can I leave, now that I feel I have come home? (202) Tamer, her cousin, gives her a lesson "You think you can come home and weave yourself back into fabric of everybody's life, then rip it out again when you leave" (206).

Gradually, Gigi begins to be fully aware of the social obligations she has to face if she is going to stay in Egypt "a dozen courtesy phone calls, visits of congratulations or condolences, lunch engagements, duties that to her unnecessary and like a frantic treadmill" (212). She starts to be overwhelmed by a strong feeling of no belongingness and feels homesickness of New Hampshire. It 
مجلة وادي النيل للاراسات والبحوث الإنسانية والاجتماعية والتربوية (مجلة علمية محكمة)

(ISSN : 2536 - 9555)

is clear now that it is her fate to live as a stranger the rest of her life with no roots.

Realizing that the house might be sold, Gigi starts to take pictures of every corner of the house that witnessed many generations of her family starting in 1910s until the new millennium and witnessed the ups and downs of her life and the political, economic, and social changes of her country. The debate related to the selling of the house makes her express the concern of most immigrants, namely, the need to come back home and find a house. She thinks:

Living abroad, I was assumed to have severed any sentimental attachments I might have. I did not occur to annoy that, precisely because I have been uprooted, I need to know that the house would be here for me to come home to. Because my past and present were irreconcilable, I needed to be able to touch base, to reconnect to my old self. The house was my link to the past, to Papa, it was part of Tarek's heritage. (222).

It is a deadly decision to leave her home and her country permanently with no return, it is like someone decides to sell his past and memories, on the plane taking back her to New Hampshire, she states that the adventure of her life is over and that , like many people who "die inside, she will keep up her routine and through duty and obligation will keep going round and round the treadmill" (233).

She then mocked the Islamization of the country at the hands of Sadat, then flooded its economy with openness, then brought the Basha (Fuad Seraj Al-Din) back as a picture or a scarecrow, leading the new Wafd Party or the "obedient opposition" as she mentioned it on his tongue, from which Al 
Disintegration of the family in Cairo House 2000 by Samia Serageldin

"A sociological literary study"

Hany Mohamed Bahaa El Deen \& Walid Abdallah Rezk

مجلة وادي النيل للاراسات والبحوث الإنسانية والاجتماعية والتربوية (مجلة علمية محكمة)

Pasha soon resigned. Then the Islamist movement grew under Mubarak, until aristocrats or their daughters began wearing the veil. Finally, he sold the palace to the wealthy Saudi prince Bandar, who became able to buy Egypt's history and present with his huge fortunes. In turn, the palace became a new prison for Princess Khadija, his wife, to sleep in it all day, wake up in the evening, and enjoy watching Egyptian movies recorded on video tapes that are shown on a huge movie screen, as was the case in Jeddah.

Abdel Nasser died and disappeared the bogyman of her childhood. He died but his features were so big in her nightmares. Every time he gave one of his speeches, Gigi feared the word that would turn their lives on its head. He always had her father prepare the bag he would take with him to prison. Abdel Nasser died, and for the street man he was the beloved ruler. His hero and the defender of his rights. A few days after his death, Um Khalil came to visit them, as was the custom since she left the service at her old age. She visited the family's homes to collect her wages and said "Our father is gone" referring to Abdel Nasser. And Gigi was amazed when she heard her, and she never thought that "Um Khalil" had this huge appreciation for the biggest enemy of the family from which she makes her living."

Since the Cairo House is regarded as an autobiography, the writer, like her heroine, must have been trying to reconcile her present with her past and to capture the world of her childhood, to keep it from running away forever, even if it was just on paper. Serageldin commented on her visits to Egypt in the 1990s saying:

Every time I was struck by the relentless pace of change sweeping every aspect of life, it seemed to me that 
مجلة وادي النيل للاراسات والبحوث الإنسانية والاجتماعية والتربوية (مجلة علمية محكمة)

(ISSN : 2536 - 9555)

soon the last traces of the world I had known would be gone with the wind" (Live in interesting Times 8).

Furthermore, in an interview with Najlaa Elhalwagy, Serageldin states that she meant her novel for the American audience by speaking of many marginalized groups in Egypt such the Nubian porters who come to work in Cairo and the zabaleen or the garbage collectors (2014) implying that 1952 revolution did not really help all people or achieved its most important goal of social justice and the immigrant families and she has succeeded in addressing both. (Elhalwagy 19).

\section{Conclusion}

Serageldin succeeds in shedding light on the dilemma of one of the aristocratic families in Egypt and explores the dark side of the 1952 Revolution from her own point of view as a representative of the high class of the Egyptian society in the twentieth century. She confirms that the revolution is the direct reason for the integration of her family, the reason for forcing her to leave her own country, the reason for her everlasting feeling of strangeness, isolation and loneliness, the reason for turning her family upside down. If the revolution succeeded in achieving the dreams of the lower class, it undoubtedly succeeded in damaging the dreams of another class whose only sin that they were classified as landowners and capitalists. Serageldin also succeeds in writing a novel that represents post-colonial literature as it embodies the main characteristics of cultural theory, "To express oneself in a language that is not one's own, a language that does not belong to one's land but has been violently imposed on it, is a source of tension that gives rise not only to feelings of alienation and uncertainty regarding the legitimacy of the mother tongue but also to confusion regarding identity." (Mambrol 2019) 
Disintegration of the family in Cairo House 2000 by Samia Serageldin

"A sociological literary study"

Hany Mohamed Bahaa El Deen \& Walid Abdallah Rezk

مجلة وادي النيل للاراسات والبحوث الإنسانية والاجتماعية والتزبوية (مجلة علمية محكمة)

\section{Works Cited}

1. Al-Raafea, Abdel Rahman, Introductions to 1925 Revolution, The Egyptian Agency of Books, 1964.

2. Ashour, Abdel Fatah. People's Revolution: The Patriotic Movement in Egypt in the $19^{\text {th }}$ and $20^{\text {th }}$ Centuries, Cairo, Dar El Nahda Al-Arabia, 1964.

3. Elhawalgy, Najlaa. Homeland Revisited, Review and Interview with Samia Serageldin, Community Times, 2001.

4. Fonon, Mohamed. The Revolution and the Anti-Revolution, Gaza, Donia El Watan, $2012 . \quad<$ https://pulpit.alwatanvoice.com/content/print/251847.html $>$.

5. Gaith, Mohamed. Social Problems and Deviant Behavior, Alexandria, Dar Al- Maarfa Al Gamiaa, 1995.

6. Khalaf, Wafaa. Mohamed Naguib and his Military and Political Role in Egypt until 1954, El Mostansria University, MA, 2006.

7. Mambrol, Nasrullah, Postcolonial Novels and Novelists, March 8, 2019.

8. https://literariness.org/2019/03/08/postcolonial-novels-andnovelists/

9. Mjaj, Lisa, Suhair. Recognized Futures, Boston South End Press, 1994.

10. Rateb, Aisha. 1952 Egypt Revolution, Cairo, Dar El Nahda AlArabia, 1964. 
11. Russell, Mona. Gender, Identity, and the Egyptian Evolution through Fact and Fiction: Hawwa, Journal of Women of the Middle East and the Islamic World, 2003.

12. Serageldin, Samia. The Cairo House, Syracuse University Press, 2000.

13. Serageldin, Samia. Live in Interesting Times. NC writers Network Newsletter, September 2000.

14. Sharobeem, Heba. Interview with Samia Serageldin, Cairo, 2012.

15. Yousif, Fatma. Theatre and Authority in Egypt from 1952 to 1970, The Egyptian Agency of Books, 1993. 